blade of a knife, the knife-edge pointing up-wind and the parent leaf forming the back.

On the largest of the ice-knives, which approached an inch in width, a regular striped pattern was evident, even from a distance of two or three yards, and closer inspection showed the same stripes on every one. These stripes were three in number, pale grey near the leaf, and again grey towards the edge of the knife, with an intervening zone of clear or yellowish ice. The grey stripes were evidently due to the presence of smoke in the cloud-mist during the daytime on November 25 and 26 , while the clear zone between had been formed from the cleaner nightwind.

At Edale Cross, I75o ft. above sea-level, the undamaged knives pointed their edges due east magnetic or directly to the centre of Sheffield. The intervening distance is more than sixteen miles, of which the first fourteen miles traverse some of the wildest moorland in England. Though I became familiar with the fouling effect of our industrial towns even on this lonely hill-country during nearly two years' residence there, yet this particular example seemed strange enough to be recorded.

W. Lawrence Balls.

The Orchard House, Bollington Cross, near Macclesfield, December I.

\section{An Oyster Spat (1921) with Mature Male Sexual Products.}

IN the course of experiments carried out this year (I92I) on the rate of growth of the slipper-limpet in the River Blackwater, Essex, I obtained a number of oyster spat on shells put in a floating raft and on clean scallop shells which were put in the water on June 9. These clean scallop shells were strung out on tarred rope at low water and kept suspended above the ground by tying the rope to stout branches of trees driven vertically into the ground. On November I6 the shells were taken out of the raft and from the shore and the new summer growth, including young oysters, examined and measured. Many of the young oyster spat measured about an inch in diameter (length anatomically) and an inch in depth (height anatomically). Some of these living spat were examined microscopically on the beds, and a few were taken back to the Plymouth Iaboratory for careful examination in the living state.

In one of the spat examined at Plymouth a few ripe sperm-morulæ were found, which disintegrated into active separate sperm while under observation under the microscope. In order to confirm this interesting observation microscopic sections were prepared, and some ripe sperm-morulæ found actually in the gonadial tubes. It is therefore established that oyster spat may produce ripe sexual products in the year in which they are born. In the experiment described here the oyster which gave mature male products had a maximum age of twenty-three weeks; it was probably younger than this, but there is no means of determining how much younger it actually was. In a paper by the present writer "Sea-temperature, Breeding, and Distribution of Marine Animals," Journ. Marine Biol. Assoc, vol, I2, No. 2, p. 352, rnzo) it was predicted that "young specimens of the European oyster ( $O$. edulis) will be found to be sexually mature in the summer in which they are spawned in those situations where high temperatures obtain for a few months." The exceptionally warm summer of $192 \mathrm{I}$ resulted in an unusually long breeding period for oysters and in "high temperatures" prevailing over English oysterbeds for several months. In I92I, therefore, the conditions over English oyster-beds compared with normal conditions in such oyster-breeding places as Arcachon, Taranto (Italy), and the spatting pools in Norway.

The abservation here yecorded is of considerable academic interest, and might become of practical interest when confirmed-as I have no doubt it can be-in a large number of specimens. Between September and November this year I have been able to examine only eight large rg2r spat, including those mentioned above. Most of them gave indications of developing sperm, but in such small quantity that microscopic sections are required of them all for confirmation. The young oyster containing ripe male sexual products was not ripe in the sense that all the gonadial tubes at the surface of the body were crammed with tailed sperm-morulæ; and although there can be no doubt that the sperm from this young oyster were mature and were capable of effecting fertilisation under suitable conditions, it is not thought probable that ripe sperm are actually extruded by such small forms. There can be no doubt, however, that similar spat would be fully mature in the following summer, and would certainly breed at least as males. This experiment, which was made possible by a grant from the Royal Society, is being continued, and should yield--together with a large amount of spat now isolated from other localities-further useful material for investigating the sex of oysters at first maturity. The gonad of the young oyster examined in all cases indicated maleness, but thé number examined is far too few to be of any value statistically. It is desirable to know the sex at first maturity of 1000 young oysters, and as young oysters have been more plentiful in most localities this year than for a good manv years, it is probable that spat born this vear can be identified with certainty now and isolated for examination next year. The sex of ro2 spat could be more easily determined in a large number of individuals next summer, and if results were recorded with accuracy from many different localities we should obtain a total of information which would help to clear up the doubtful question of the sex of the European oyster at its first maturity.

J. H. ORTON. Plymouth, December 5 .

\section{The Flight of Thistledown.}

Mr attention has been directed to the letters in NaTuRE of October 20 and November to on the flight of thistledown. The explanation of the phenomenon observed seems to me to lie in the very slow aircurrents which are sufficient to raise the pappose structures of many Compositæ, especially when it is only the pappus which is raised, the fruit having fallen off.

Interested readers will find the hydrodynamics of fruit dispersal by wind discussed in some detail in my "Origin and Development of the Compositæ" (Wheldon and Wesley, London, I919), and more briefly in my "Text-book of Botany" (Churchill, London, 1921). Some of the results given may be of general interest, e.g. the minimum winds which will raise the following pappose fruits (with fruit attached) are: dandelion, I m.p.h., groundsel, $\frac{2}{3}$ m.p.h. The pappus alone would be lifted by a much slower wind, as is shown by the fact that a current of air moving at $0.59 \mathrm{~m} . \mathrm{p} . \mathrm{h}$. is sufficient to blow the complete fruit of coltsfoot for a considerable distance horizontally.

Department of Botany, Queen's University, Belfast, December 2.

NO. 2720 , VOL. $10 \ell$, 